\title{
Eight Decades of Psi Research: Highlights in the Journal of Parapsychology
}

\author{
Carlos S. Alvarado ${ }^{1}$ \\ Parapsychology Foundation
}

\begin{abstract}
This is a short review of the $\mathbf{8 0}$ years of existence of the Journal of Parapsychology. Founded in 1937, the journal articulated the experimental research program of J. B. Rhine and his associates at Duke University. Highlights of the journal are discussed, starting with examples of articles reporting experiments of extrasensory perception and psychokinesis. Also discussed are articles about spontaneous cases, the presentation of novel and creative approaches, critiques and discussions, overviews of the field, J. B. Rhine's use of the Journal of Parapsychology to prescribe for the field, and concepts and theories. The Journal of Parapsychology is seen as an important influence in the development of parapsychology.
\end{abstract}

Keywords: Journal of Parapsychology; J. B. Rhine; experimental parapsychology; spontaneous case studies; influence of journals

This anniversary of the publication of the Journal of Parapsychology brings to mind the works of many authors over the years who have contributed to the development of modern parapsychology. In this paper I present a few examples of various topics discussed throughout the life of the JP hoping to illustrate the importance of the journal for parapsychology. ${ }^{2}$

\section{Experimental Research}

Following the appearance of J.B. Rhine's Extra-Sensory Perception (1934), the JP was founded in 1937 mainly to publish experiments conducted with ESP cards. The opening editorial published in the first issue of the journal stated:

Parapsychology is a word that comes to us from Germany... We think it may well be adopted into the English language to designate the more strictly experimental part of the whole field implied by psychical research ... We do not claim that any sharp line can be drawn marking off the field of parapsychology within the larger vaguer province of psychical research. Rather, we anticipate that the stricter experimental methods will gradually invade other parts of the province annexing them to their own more special field, until possibly the two shall coin-

\footnotetext{
1 I am grateful to the journal's editor for inviting me to submit this paper I wish to thank Nancy L. Zingrone for editorial suggestions. James Carpenter kindly gave me information about some of his papers. Address correspondence to: Carlos S. Alvarado, Ph. D., Parapsychology Foundation, P.O. Box 1562, New York, NY, 10021, carlos@theazire.org.

2 The discussion below is but a brief overview of selected topics from the JP for the 1937-2017 period. To keep the discussion short, I focus on articles, to the neglect of correspondence and book reviews. More details on the topic appear in an article I wrote for the Psi Encyclopedia (Alvarado, in press).
} 
cide. But we regard the differentiation of the two terms as useful at the present time; and it is our intention to admit to this journal only contributions that properly fall within the narrower sphere implied by its title; that is to say, reports of experimental studies in the stricter sense and discussions of methods and interpretations of such work. (McDougall, 1934, p. 7) ${ }^{3}$

Illustrating this agenda, during the first ten years of the JP 52\% of the articles published were reports of experiments. In contrast, only $11 \%$ of the total number of papers that appeared in the other important American journal, the Journal of the American Society for Psychical Research, were experiments (Zingrone, 1988, p. 332). These were highly exploratory days in which many topics were investigated to learn more about ESP functioning. This included such varied things as comparison of different techniques to test for ESP (Gibson, 1937), and of various distances from the targets (J. B. Rhine, 1937a). Regarding distance, Rhine (1937) concluded:

The work already reported seems to show that distance does not limit ESP as it does sensory perception. Particularly those Duke experiments known as the Pearce-Pratt and the Turner-Ownbey series demonstrate this by reason of the control series needed for comparison. In a total of 101,450 trials in which distance was a condition and which gave as a whole a significant deviation, there was shown in the two series in which there were score averages at different distances that there was no proportionate falling off of average with distance, such as a mechanical analogy would require. In fact, it would appear that no falling off whatever directly occurs with spatial separation. (p. 184)

These initial explorations include different types of participants, such as the mentally retarded (Bond, 1937), twins (Kubis \& Rouke, 1937), and the blind (Price \& Pegram, 1937), as well as the impact of psychological variables on ESP scoring. Among these were intelligence (Humphrey, 1945) and the relationship between participants and experimenters (Pratt \& Price, 1938). Explorations of psychological correlates of ESP are still conducted, having been recorded in the JP more recently as can be seen in Honorton's (1997) ganzfeld report and in other work (Haraldsson, Houtkooper, Schneider, \& Bäckstrom, 2002) as well.

Starting in the 1940s, the JP also became the repository of various reports about psychokinesis (PK) using dice, many of which had remained unpublished from the $1930 \mathrm{~s} .{ }^{4}$ The abstract of the first report on the subject, authored by J. B. and Louisa E. Rhine (1943), reads:

The test procedure consisted of dice-throwing, in which a pair of common dice was thrown either by hand or by a semi-mechanical method. The objective was to cause them to come up as "high dice," i.e., with faces totaling 8 or above. A "run" consisted of 12 throws of the pair and the expectation for each run was 5 successes ( 8 or above); the average score obtained for the 562 runs that were made was actually 5.53. This represents a total score that is 300 hits above the total expectation from chance ..., which represents extremely high odds against the likelihood of such results occurring by chance. (p. 20)

3 This editorial, which was not signed, was attributed to William McDougall (Mauskopf \& McVaugh, 1980, p. 147).

4 For details about the development of the early PK dice work, see L. E. Rhine (1970). 
Like the ESP work, soon there were studies published to try to understand PK via the explorations of the effects of other variables on PK scoring. Among these studies were those that investigated the effects of alcohol on PK test performance (Averrill \& Rhine, 1945), and the impact on scoring of different sizes of dice (Hilton, Baer, \& Rhine, 1943).

The topic of PK was less popular in the JP than ESP, but it continued to appear in later work. Edward Cox's (e.g., 1965) work with various devices, Helmut Schmidt's (1970) use of random number generators, and more recent tests exploring mental strategies and feedback (e.g., Roe \& Holt, 2006) are examples of these type of experiments. The modern period also included work with biological targets (e.g., Braud \& Schlitz, 1983). All these explorations, and particularly the early ones published during the 1930 s and the 1940s, were fundamental for the development of modern experimental parapsychology.

\section{Work with Spontaneous Cases}

The articles of Louisa E. Rhine about ESP cases are perhaps the best-known publications about spontaneous cases in the history of the JP. Even though she did not consider that cases could provide evidence for the existence of ESP, she explored her cases - mainly obtained through correspondence to Duke University's Parapsychology Laboratory - for the purpose of identifying testable hypotheses for experiments. ${ }^{5}$

In an early paper about the types of ESP experiences, L.E. Rhine (1953) wrote:

Four main types were found: (1) Intuitive, in which the subject's experience was a simple, unreasoned impression or hunch. (2) Hallucinatory, in which the experience was projected as if it were a sensation. (3) Unrealistic dreaming, in which the experience was characterized by fantasy. (4) Realistic dreaming, in which the imagery was almost photographically realistic. (p. 77)

Rhine continued her analyses over the years. She considered such topics as different types of precognition (L. E. Rhine, 1954), veridical hallucinations (L. E. Rhine, 1956), and completeness of information in dream and waking experiences (L. E. Rhine, 1962a, 1962b).

Over the years, several other papers about spontaneous experiences appeared. A particularly influential paper, important for the modern history of poltergeist research, was Pratt and Roll's (1958) report of a case in Seaford, Long Island. In this paper the authors introduced the term recurrent spontaneous psychokinesis (RSPK) to refer to poltergeists. This was followed in later years by other reports of poltergeists and hauntings (Kruth \& Joines, 2016; Maher, 2000).

More recently questionnaire surveys about a variety of psychic experiences in relation to experimental ESP scores and personality variables (Haight, 1979), and psychoactive drugs (Luke \& Kittenis, 2005) have been published.

5 All this work was summarized years later by L. E. Rhine (1981), and by Weiner and Haight (1983). It is debatable if this work was really useful to generate testable ideas to conduct experiments. 


\section{Novel and Creative Approaches to Research}

Among the many research reports published in the $J P$, there were some that may be considered to be particularly creative due to their innovative research approaches. An early example was a protocol for the study of "pure" telepathy by Elizabeth McMahan (1946). As she described her procedure:

An ESP experiment was conducted in such a way as to allow telepathy to function, but not clairvoyance or precognition. The sender thought of one of the ESP symbols without making any objective record of it except through a code number, while the receiver in another room tried to identify the symbol. The code was communicated to an assistant experimenter by means of reference to common memories which had no objective basis and hence were inaccessible to clairvoyance. Significant results were obtained. (p. 224, abstract)

Other innovations were studies attempting to influence cats conducted by Karlis Osis (1952), which, even if unimpressive today for its attempts to control for sensory cues, represented an innovative step forward in the study of animal ESP at the time. Several fascinating study designs developed over the decades include experiments to assess whether the identity of the person checking results could affect ESP scores (Feather \& Brier, 1968), the use of random event generators (Schmidt, 1969), and the application of repeated guessing and majority vote analysis to detect Morse encoded words as ESP targets (Carpenter, 1991).

Another creative approach was the use of anesthetized mice as targets in attempts to test the possibility of psychic resuscitation (Watkins \& Watkins, 1971). As the authors wrote in their abstract:

Twelve subjects (nine of them professed "psychics" or known to be exceptional performers on PK or ESP tests) were tested for their ability to cause mice to arouse more quickly from ether anesthesia than normally would be expected. Pairs of mice (Swiss-Webster) were simultaneously rendered unconscious .... with ... ether. The pairs were of the same sex, comparable size, and were litter mates. After both mice were unconscious, ... the subject was told to attempt to awaken his or her mouse. The other mouse was used as a control ... The results were highly significant overall ..., the experimental animal requiring $87 \%$ as much time to awaken as the control. (Watkins \& Watkins, 1971, p. 257)

\section{Critiques and Discussions}

Criticism has appeared in the pages of the JP from its early days, an example of which was a discussion of the problem of premature stopping of experiments (Lemmon, 1939). In later years, space was provided in the journal to other criticisms such as those arguing for conventional explanations of experimental results on the basis of problems with the randomization of targets (Gilmore, 1989). In fact, a summary of the well-known critique of ESP research authored by George R. Price in Science, in which he suggested the possibility of experimenter fraud, was published as well in the JP (Price, 1955). ${ }^{6}$ The editor of the JP also included replies to Price that had been published first in Science. The willingness to entertain criticisms seriously was the way the JP made the point that parapsychology is open to criti-

6 Price later changed his mind and apologized publicly (Price, 1972). 
cism, but that criticism might be effectively countered as well. Later critics in the journal included C.E.M. Hansel (1961) and Richard Wiseman and Julie Milton (1998).

In fact, from its early days, the JP has been an effective forum in which to respond to criticisms of parapsychological research, as can be seen in Charles Stuart's rebuttal published in 1938. Stuart concluded that the criticisms of the Duke work by psychologists could be improved. He wished for a more systematic examination of the data, hoping that a "willingness to face the issues directly in terms of the evidence and the experimental methods available the present difference between critical and experimental conclusions might be happily resolved" (p. 320).

Other reply to critics included J.B. Rhine and J.G. Pratt's (1961) defense of the Pearce-Pratt experiment. More recently, the JP republished an important paper by Charles Honorton (1993) in which he summarized, and critiqued both the assumptions and main arguments of the critics of experimental research in parapsychology, finding them to be lacking.

Also important were papers whose two authors, one a "proponent" of the field (Honorton, 1985), and the other a critic (Hyman, 1985) defended and criticized ganzfeld ESP research. The interaction of these two individuals produced a joint article that, at the time, was considered to have provided a constructive opportunity for dialog and a possible guide for further research collaborations (Hyman \& Honorton, 1986). Unfortunately, these efforts, and later special issues of the JP devoted to discussing ganzfeld work (December, 1986, and December, 1999), did not significantly bring more acceptance of the research work.

\section{Charting the Field}

An important function of the JP, and of other journals, has been to help us understand the state of the field, in terms of findings and problems, mainly done through overview papers. A very interesting, but now forgotten one was a summary of comments from the literature about variables that favor the appearance of ESP (Smith \& Gibson, 1941). Among the topics considered were concentration, disposition, distraction, excitement, interest, mood, personality, and relaxation.

This was followed in later years by reviews of many topics. Among these were examinations of veridical perception during out-of-body experiences (Alvarado, 1982), and of experimenter effects (Kennedy \& Taddonio, 1976), among others.

More than other parapsychology journals, the JP has been a pioneer in the publication of meta-analyses on various lines of research, among them, ESP in the ganzfeld (Honorton, 1985), precognition (Honorton \& Ferrari, 1989), a comparison of clairvoyance and precognition conditions (Steinkamp, Milton, \& Morris, 1998), and forced choice ESP tests (Storm, Tressoldi, \& Di Risio, 2012).

Many productive and informative literature review papers published by the journal were not focused on research. Examples of this type of papers included work related to psychiatry (Eisenbud, 1949), the language barrier in parapsychology (Alvarado, 1989), parapsychological developments in Ibero-America (Rueda, 1991), and a sociology of science approach to controversy in the field (Zingrone, 2002). 


\section{J. B. Rhine's Use of the JP}

Academic journals are well known for their sometimes quite intentional influence on their fields accomplished by the emphases its editors place on specific approaches, methodologies, and conceptual frameworks. From this perspective, it has been stated that J. B. Rhine "tried to chart the course of the field [in the JP] by dispensing his advice, his approval and disapproval, as he sought to shape parapsychology according to his views and priorities" (Alvarado, 2011, p. 95). His particular method of influence were embodied in Rhine's numerous editorials.

These editorials gave prescriptions about the coining of terms in the field (J. B. Rhine, 1945), the application of the scientific method (J. B. Rhine, 1947), and the proper use of spontaneous cases (J. B. Rhine, 1948). Regarding the latter, Rhine said:

Because of the elusive nature of ESP phenomena, it has not been easy to follow up experiences with experiments which would produce evidential results on demand. Accordingly, there has been a great deal of effort to recruit and dress up these spontaneous experiences themselves as evidence of reliable character, but all attempts to authenticate the reports well enough to allow reliable conclusions to be drawn have been comparatively unsuccessful. The result of this abuse of the case report has been a misunderstanding of its true significance and usefulness ... If, however, the spontaneous experience can be given its proper role, it can play a great part in the researches ahead, perhaps a crucially important one. Such material can help us to initiate new experimental approaches, not any longer to establish psi, but to find out more about what it is and how it operates (p. 232).

Rhine was also concerned about the boundaries of parapsychology, that is, what was and what was not part of the subject matter of the field. Regarding Kirlian photography, he wrote that because it "has not been reliably reported to have anything to do with psi" it should not be a topic for the field (Rhine, 1972, p. 171). Similarly, he discouraged interest in what he felt the scientific method could not solve. This included such topics as survival of death (J.B. Rhine, 1974).

Of course, over the years, many other authors have presented their views and suggestions about many topics of interest in the field (e.g., Alvarado, 2002; Murphy, 1948), ${ }^{7}$ but my impression is that no other author exceeded Rhine in this, and no one used editorials in the same way. In recent times, though, the current editor of the JP has started to contribute some thought-provoking editorials (e.g., Cardeña, 2017).

\section{Theoretical Issues}

The JP was not known for including many theoretical discussions. But the topic was not completely neglected, as can be seen in early articles about ESP (Reiser, 1939; Saltmarsh, 1942). Thouless and Wiesner (1948) wrote that ESP and PK are

7 There have been special issues of the JP in which many individuals presented their opinions and recommendations about parapsychological research (March, 1948; June, 1948; December 2012). 
unusual forms of processes which are themselves usual and commonplace, and that in their usual and common place form, they are to be found as elements in the normal processes of perception and motor activity... The hypothesis we wish to suggest is that, in normal thinking and perceiving I am in the same sort of relation to what is going on in the sensory part of my brain and nervous system as that of the successful clairvoyant to some external event, and that this relation is established by the same means ... (pp. 195-196).

Other models have been proposed in the journal regarding out-of-body experiences (Blackmore, 1984), precognition (Marwaha \& May, 2015), and other topics (e.g., May, Utts, \& Spottiswoode, 1995). It was in the JP where James Carpenter $(2004,2005)$ first presented his First Sight model. ${ }^{8}$ He wrote:

This model assumes that each organism, by its nature, extends beyond itself into the larger pre-sensory surround. Psi is assumed to be neither knowledge nor action, but to belong to the outermost temporal edge of those normal pre-experiential mental processes by which the mind structures all its experiences and commences all its actions. Psi processes are posited to function normally as the unconscious leading edge of the development of all consciousness and all intention. This unconscious functioning is normal and continuous, and is a constituent element of all experience ... It is assumed that unconscious mental processes, including psi processes, are motivated by personal intentions and needs, also largely unconscious. (Carpenter, 2004, p. 217).

Unlike other journals, the issue of survival of death has not received much attention, but there have been important exceptions, as seen in the writings of J. B. Rhine $(1956,1974)$. During the 1960s, seven papers appeared in the JP first presented in 1959 at a conference sponsored by the Parapsychology Laboratory called "Symposium on Incorporeal Personal Agency" (e.g., Roll, 1960).

There were also some debates that took place in correspondence, such as that of Hornell Hart (1957) and Louisa Rhine (1957). Exchanges like these were valuable in that they illustrated the different conceptual assumptions behind phenomena considered by some to be evidence of survival of death.

\section{Concluding Remarks}

I am afraid that my attempt at keeping this article short, as commissioned, may not have done justice to the richness of the content of the last 80 years of the JP. In addition to mentioning only a small number of papers, I have not covered at all some areas and topics. Among the areas omitted are articles about the future of the field, discussions of the history of parapsychology and of the beginnings of the journal, and the participation of non-American authors in the journal. Furthermore, more could be said about the disciplinary approach to the field's phenomena and theory as represented by authors from psychology, physics, philosophy, and other scientific and scholarly perspectives.

The appearance of the JP represents a change from the psychical research tradition that existed in the United States and elsewhere before the late 1930s, which was dominated by the study of cases and of mediumship (Inglis, 1984). Although the research program of J.B. Rhine and his associates was 
to some extent a reinstatement of earlier interest in experimentation, the JP greatly assisted the development of parapsychology. This was accomplished by providing a forum that assisted processes such as the standardization of techniques to assess chance, controls for contaminating factors such as sensory cues, and terminology in parapsychology (on this later issue see Zingrone \& Alvarado, 1987) 9 . Like every good scientific journal, the JP also facilitated communication between researchers and others in the field helping to disseminate ideas and encourage professional attitudes. The presentation of information, in the form of reviews of the literature, and book reviews (not discussed in this paper) has made the journal an essential reference source over the years for researchers, students, and others. One hopes that this tradition of excellence and dedication continues beyond this anniversary as parapsychology moves to new horizons.

\section{References}

Alvarado, C.S. (1982). ESP during out-of-body experiences: A review of experimental studies. Journal of Parapsychology, 46, 209-230.

Alvarado, C. S. (1989). The language barrier in parapsychology. Journal of Parapsychology, 53, 125-139.

Alvarado, C. S. (2003). Guest editorial: Thoughts on the study of spontaneous cases. Journal of Parapsychology, 66, 115-125.

Alvarado, C. S. (2011). Prescribing for parapsychology: Note on J.B. Rhine's writings in the Journal of Parapsychology. Australian Journal of Parapsychology, 11, 89-99.

Alvarado, C.S. (in press) Journal of Parapsychology. Psi Encyclopedia.

Alvarado, C. S., Biondi, M., \& Kramer, W. (2006). Historical notes on psychic phenomena in specialised journals. European Journal of Parapsychology, 21, 58-87.

Averill, R. L., \& Rhine, J. B. (1945). The effect of alcohol upon performance in PK tests. Journal of Parapsychology, 9, 32-41.

Blackmore, S.J. (1984). A psychological theory of the out-of-body experience. Journal of Parapsychology, 48, 201-218.

Bond, E.M. (1937). General extra-sensory perception with a group of fourth and fifth grade retarded children. Journal of Parapsychology, 1, 114-122.

Braud, W., \& Schlitz, M. (1983). Psychokinetic influence on electrodermal activity. Journal of Parapsychology, 47, 95-119.

Cardeña, E. (2017). Editorial: On scientific amnesia. Journal of Parapsychology, 81, 104-105.

Carpenter, J. C. (1991). Prediction of forced-choice ESP performance: Part III. The attempts to retrieve coded information using mood reports and a repeated guessing technique. Journal of Parapsychology, 55, 227-280.

Carpenter, J. C. (2004). First Sight: Part one: A model of psi and the mind. Journal of Parapsychology, 68, 217-254.

Carpenter, J. C. (2005). First Sight: Part two: Elaboration of a model of psi and the mind. Journal of Parapsychology, 69, 63-112.

Carpenter, J. C. (2012). First sight: ESP and parapsychology in everyday life. Lanham, MD: Rowman \& Littlefield.

Cox, W.E. (1965). The effect of PK on electromechanical systems. Journal of Parapsychology, 29, 165-175.

Eisenbud, J. (1949). Psychiatric contributions to parapsychology: A review. Journal of Parapsychology, 13, 247-262.

9 Although it has to be recognized that other journals also affected the development of parapsychology (Alvarado, Biondi \& Kramer, 2006), none of them has been so influential on statistically-evaluated experimental research in the modern period as the JP. 
Feather, S. R., \& Brier, R. (1968). The possible effect of the checker in precognition tests. Journal of Parapsychology, 32, 167-175.

Feller, W. K. (1940). Statistical aspects of ESP. Journal of Parapsychology, 4, 271-298.

Gilmore, J. B. (1989). Randomness and the search for psi. Journal of Parapsychology, 53, 309-340.

Haight, J.M. (1979). Spontaneous psi cases: A survey and preliminary study of ESP, attitudes, and personalit y relationships. Journal of Parapsychology, 43, 179-204.

Hansel, C. E. M. (1961). A critical analysis of the Pearce-Pratt experiment. Journal of Parapsychology, 25, 87-91.

Hart, H. (1957). Mrs. Rhine's conclusions about survival: A critique. Journal of Parapsychology, 21, 227237.

Honorton, C. (1985). Meta-analysis of psi ganzfeld research: A Response to Hyman. Journal of Parapsychology, 49, 51-91.

Honorton, C. (1993). Rhetoric over substance: The impoverished state of skepticism. Journal of Parapsychology, 57, 191-214.

Honorton, C. (1997). The ganzfeld novice: Four predictors of initial ESP performance. Journal of Parapsychology, 61, 143-158.

Honorton, C., \& Ferrari, D. C. (1989). "Future telling": A meta-analysis of forced-choice precognition experiments, 1935-1987. Journal of Parapsychology, 53, 281-308.

Humphrey, B.M. (1945). ESP and intelligence. Journal of Parapsychology, 9, 7-16.

Hyman, R. (1985). The ganzfeld psi experiment: A critical appraisal. Journal of Parapsychology, 49, 3-49.

Hyman, R., \& Honorton, C. (1986). A joint communique: The psi Ganzfeld controversy. Journal of Parapsychology, 50, 351-364.

Inglis, B. (1984). Science and parascience: A history of the paranormal, 1914-1939. London: Hodder and Stoughton.

Kennedy, J. E., \& Taddonio, J. L. (1976). Experimenter effects in parapsychological research. Journal of Parapsychology, 40, 1-33.

Kruth, J. G., \& Joines, W. T. (2016). Taming the host within: An approach toward addressing apparent electronic poltergeist activity. Journal of Parapsychology, 80, 70-86.

Kubis, J. F., \& Rouke, F. L. (1937). An experimental investigation of telepathic phenomena in twins. Journal of Parapsychology, 1, 163-171.

Lemmon, V.W. (1939). The role of selection in ESP data. Journal of Parapsychology, 3, 104-106.

Luke, D. P., \& Kittenis, M. (2005). A preliminary survey of paranormal experiences with psychoactive drugs. Journal of Parapsychology, 69, 305-327.

Maher, M. C. (2000). Quantitative Investigation of the General Wayne Inn, Journal of Parapsychology, 64, 365-390.

Marwaha, S. B., \& May, E. C. (2015). The multiphasic model of precognition: The rationale. Journal of Parapsychology, 79, 5-19.

Mauskopf, S. H., \& McVaugh, M. R. (1980). The elusive science: Origins of experimental psychical research. Baltimore: John Hopkins University Press.

May, E. C., Utts, J. M., \& Spottiswoode, S. J. . (1995). Decision augmentation theory: Toward a model of anomalous mental phenomena. Journal of Parapsychology, 59, 195-220.

[McDougall, W. ]. (1937). Editorial introduction. Journal of Parapsychology, 1, 1-9.

McMahan, E. (1946). An experiment in pure telepathy. Journal of Parapsychology, 10, 224-242.

Murphy, G. (1948). What needs to be done in parapsychology. Journal of Parapsychology, 12, 15-19.

Osis, K. (1952). A test of the occurrence of a psi effect between man and the cat. Journal of Parapsychology, 16, 233-256.

Pratt, J. G., \& Price, M. M. (1938). The experimenter-subject relationship in tests for ESP. Journal of Parapsychology, 2, 84-94. 
Pratt, J. G., \& Roll, W. G. (1958). The Seaford disturbances. Journal of Parapsychology, 22, 79-124.

Price, G. R. (1955). Science and the supernatural. Journal of Parapsychology, 19, 238-241.

Price, G. R. (1972). Letter to the editor. Science, 175, 359.

Price, M. M., \& Pegram, M. H. (1937). Extra-sensory perception among the blind. Journal of Parapsychology, 1, 143-155.

Reiser, O. L. (1939). A theory of extra-sensory perception. Journal of Parapsychology, 3, 167-193.

Rhine, J. B. (1934). Extra-sensory perception. Boston, MA: Boston Society for Psychic Research.

Rhine, J. B. (1937). The effect of distance in ESP tests. Journal of Parapsychology, 1. 171-184.

Rhine, J. B. (1942). Editorial: Hypnotism. "graduate" of parapsychology. Journal of Parapsychology, 6 , 159-163.

Rhine, J. B. (1945b). Editorial: A proposed basis for choosing terms in parapsychology. Journal of Parapsychology, 9, 147-149.

Rhine, J. B. (1947). Impatience with scientific method in parapsychology. Journal of Parapsychology, 11, 283-295.

Rhine, J. B. (1948b). Editorial: The value of reports of spontaneous psi experiences. Journal of Parapsychology, 12, 231-235.

Rhine, J. B. (1953a). Editorial: Parapsychology and its personnel. Journal of Parapsychology, 17, 1-5.

Rhine, J. B. (1956b). Research on spirit survival re-examined. Journal of Parapsychology, 20, 121-131.

Rhine, J. B. (1972a). News and comments: Is parapsychology losing its way? Journal of Parapsychology, $36,170-176$.

Rhine, J. B. (1972b). Parapsychology and man. Journal of Parapsychology, 36, 101-121.

Rhine, J. B. (1974b). Telepathy and other untestable hypotheses. Journal of Parapsychology, 38, 137-153.

Rhine, J. B., \& Pratt, J. G. (1961). A reply to Hansel's critique of the Pearce-Pratt series. Journal of Parapsychology, 25, 92-98.

Rhine, L. E. (1953). Subjective forms of spontaneous psi experiences. Journal of Parapsychology, 17, 77-114.

Rhine, L. E. (1954). Frequency and types of experience in spontaneous precognition. Journal of Parapsychology, 18, 93-123.

Rhine, L. E. (1956a). Hallucinatory psi experiences: II The initiative of the percipient in hallucinations of the living, the dying, and the dead. Journal of Parapsychology, 21, 13-46.

Rhine, L. E. (1957). [Reply to H. Hart]. Journal of Parapsychology, 22, 237.

Rhine, L. E. (1962a). Psychological processes in ESP experiences: Part I. Waking experiences. Journal of Parapsychology, 26, 88-111.

Rhine, L. E. (1962b). Psychological processes in ESP experiences: Part II. Dreams. Journal of Parapsychology, 26, 172-199.

Rhine, L. E. (1970). Mind over matter: Psychokinesis. New York, NY: Macmillan.

Rhine, L. E. (1981). The invisible picture: A study of psychic experiences. Jefferson, NC: McFarland.

Roe, C. A., \& Holt, N. J. (2006). The effects of strategy ("willing" versus absorption) and feedback (immediate versus delayed) on performance at a PK task. Journal of Parapsychology, 70, 69-90.

Roll, W.G. (1960). The contribution of studies of "mediumship' to research on survival after death. Journal of Parapsychology, 24, 258-178.

Rueda, S. A. (1991). Parapsychology in the Ibero American world: Past and present developments. Journal of Parapsychology, 55, 175-207.

Saltmarsh, H. F. (1942). The nature of extra-sensory perception. Journal of Parapsychology, 6, 101-110. Schmidt, H. (1970). A PK test with electronic equipment. Journal of Parapsychology, 34, 175-182.

Shulman, R. (1938). A study of card guessing in psychotic subjects. Journal of Parapsychology, 2, 95-106. Smith, B.M., \& Gibson, E.P. (1941). Conditions affecting ESP performance. Journal of Parapsychology, 5 , 58-86. 
Steinkamp, F., Milton, J., \& Morris, R.L. (1998). A meta-analysis of forced-choice experiments comparing clairvoyance and precognition. Journal of Parapsychology, 62, 193-218.

Storm, L., Tressoldi, P., \& Di Risio, L. (2012). Meta-analysis of ESP studies, 1987-2010: Assessing the success of the forced-choice design in parapsychology. Journal of Parapsychology, 76, 243-273.

Stuart, C. (1938). A review of recent criticisms of ESP research. Journal of Parapsychology, 2, 308-321.

Thouless, R. H., \& Wiesner, B. P. (1948). The psi process in normal and "paranormal" psychology. Journal of Parapsychology, 12, 192-212.

Watkins, G.K., \& Watkins, A. M. (1971). Possible PK influence on the resuscitation of anesthetized mice. Journal of Parapsychology, 35, 257-272.

Weiner, D.H., \& Haight, J. (1983). Charting hidden channels: A review and analysis of Louisa E. Rhine's case collection project. Journal of Parapsychology, 47, 303-322.

Zingrone, N. L. (1988). Authorship and gender in American parapsychology journals. Journal of Parapsychology, 52, 321-343.

Zingrone, N.L. (2002). Controversy and the problems of parapsychology. Journal of Parapsychology, 66, 3-30.

Zingrone, N. L., \& Alvarado, C.S. (1987). Historical aspects of parapsychological terminology. Journal of Parapsychology, 51, 49-74.

\section{Huit décennies de recherche psi : Faits saillants du Journal of Parapsychology}

Résumé : Cet article est un bref passage en revue de 80 années d'existence du Journal of Parapsychology. Fondé en 1937, le journal servait de tribune au programme de recherche expérimentale de J. B. Rhine et ses associés à l'Université de Duke. Les faits saillants du journal sont discutés, à commencer par des exemples d'articles reportant des expérimentations de perception extra-sensorielle et de psychokinèse. Sont également discutés des articles sur des cas spontanés, la présentation d'approches nouvelles et créatives, des critiques et des discussions, des vues d'ensemble du champ, ainsi que la façon dont J. B. Rhine utilisait le Journal of Parapsychology pour faire des prescriptions quant à l'évolution de la discipline, en y introduisant des concepts et des théories. Le Journal of Parapsychology y apparaît comme une influence importante dans le développement de la parapsychologie.

\section{Acht Jahrzehnte Psi-Forschung: Höhepunkte im Journal of Parapsychology}

Zusammenfassung: Dies ist ein kurzer Überblick über das 80jährige Bestehen des Journal of Parapsychology. Die 1937 gegründete Zeitschrift war das Sprachrohr für das experimentelle Forschungsprogramm von J. B. Rhine und seinen Mitarbeitern an der Duke University. Höhepunkte der Zeitschrift werden diskutiert, beginnend mit Beispielen von Artikeln, die über Experimente zur außersinnlichen Wahrnehmung und Psychokinese berichten. Diskutiert werden außerdem Artikel über Spontanberichte, die Vorstellung neuer und kreativer Forschungsansätze, Kritiken und Diskussionen, Übersichten über das gesamte Gebiet, J. B. Rhines Nutzung des Journal of Parapsychology, um das Forschungsfeld zu umreißen einschließlich der Konzepte und Theorien. Die wichtige Bedeutung des Journal of Parapsychology für die Entwicklung der Parapsychologie wird betont. 


\section{Ocho Décadas de Investigación: Lo Más Destacado en el Journal of Parapsychology}

Resumen: Esta es una breve reseña de 80 años de existencia del Journal of Parapsychology. Fundada en 1937, la revista articuló el programa de investigación experimental de J. B. Rhine y sus asociados en la Universidad de Duke. Se discuten los aspectos más destacados de la revista, comenzando con ejemplos de artículos que describieron experimentos de percepción extrasensorial y psicoquinesis. También se mencionan artículos sobre casos espontáneos, la presentación de enfoques novedosos y creativos, críticas y discusiones, descripciones generales del campo, el uso de J. B. Rhine del Journal of Parapsychology para dirigir el campo, y conceptos y teorías. El Journal of Parapsychology ha sido una influencia importante en el desarrollo de la parapsicología. 